\title{
Bartonella schoenbuchii sp. nov., isolated from the blood of wild roe deer
}

\footnotetext{
${ }^{1}$ Abt. Molekulare Mikrobiologie, Biozentrum der Universität Basel, Klingelbergstrasse 70, $\mathrm{CH}-4056$ Basel, Switzerland

2 Abt. Infektionsbiologie, Max-Planck-Institut für Biologie, Tübingen, Germany

3 Staatliches Forstamt Tübingen-Bebenhausen, Tübingen, Germany

4 Veterinäramt Tübingen, Tübingen, Germany

5 Institut de Bactériologie de la Faculté de Médecine, Université Louis-Pasteur, Hôpitaux, Universitaires de Strasbourg, France

6 Institut für Medizinische Mikrobiologie und Hygiene, Universität Freiburg, Germany
}

\author{
Christoph Dehio, ${ }^{1,2}$ Christa Lanz, ${ }^{2}$ Rainer Pohl, ${ }^{3}$ Peter Behrens, ${ }^{4}$ \\ Delphine Bermond, ${ }^{5}$ Yves Piémont, ${ }^{5}$ Klaus Pelz $^{6}$ and Anna Sander ${ }^{6}$
}

Author for correspondence: Christoph Dehio. Tel: +4161267 2140. Fax: +41612672118. e-mail: christoph.dehio@unibas.ch

\begin{abstract}
The genus Bartonella comprises two human-specific pathogens and a growing number of zoonotic or animal-specific species. Domesticated as well as wild mammals can serve as reservoir hosts for the zoonotic agents and transmission to humans may occur by blood sucking arthropods or by direct blood to blood contact. Humans may come into intimate contact with free-ranging mammals during hunting, especially during evisceration with bare hands, when accidental blood to blood contact frequently occurs. The objective of this work was to determine the presence and the polymorphism of Bartonella strains in wild roe deer (Capreolus capreolus) as the most widely spread game in Western Europe. We report the isolation of four Bartonella strains from the blood of five roe deer. These strains carry polar flagella similar to Bartonella bacilliformis and Bartonella clarridgeiae. Based on their phenotypic and genotypic characteristics, three of the four roe deer isolates were different and they were all distinct from previously described Bartonella species. They can be distinguished from each other and from other Bartonella species by their protein profile, ERIC-PCR pattern, 16S rRNA and citrate synthase (gltA) gene sequences, as well as by whole DNA-DNA hybridization. In spite of their considerable heterogeneity, all four strains fulfil the criteria for belonging to a single new species. The name Bartonella schoenbuchii is proposed for this new species. The type strain $\mathrm{R1}^{\top}$ of Bartonella schoenbuchii has been deposited in the National Collection of Type Cultures as NCTC $13165^{\top}$ and the Deutsche Sammlung von Mikroorganismen und Zellkulturen as DSM 13525'.
\end{abstract}

Keywords: Bartonella schoenbuchii, roe deer, zoonoses

\section{INTRODUCTION}

The genus Bartonella comprises small, curved, often piliated or flagellated bacteria, which have been cultured in recent years on axenic media from the blood of many mammalian hosts (Dehio \& Sander, 1999). Together with the reclassification of bacteria formerly belonging to the genera Rochalimaea and Grahamella (Brenner et al., 1993; Birtles et al., 1995) this has resulted in a dramatic expansion of the genus

Abbreviation: ERIC-PCR, enterobacterial repetitive intergenic consensus PCR.

The EMBL accession numbers for the 16S rRNA genes of Bartonella schoenbuchii NCTC $13165^{\top}\left(\mathrm{R}^{\top}\right), \mathrm{R} 3, \mathrm{R} 4$ and R6 are AJ278187, AJ278188, AJ278189 and AJ278190, respectively. The EMBL accession numbers for the gltA genes of Bartonella schoenbuchii NCTC $13165^{\top}\left(\mathrm{R} 1^{\top}\right), \mathrm{R} 3$, R4 and R6 are AJ278183, AJ278184, AJ278185 and AJ278186, respectively.
Bartonella from one described species in 1993 to currently 15 species, among which at least seven have been associated with human disease (Dehio \& Sander, 1999). A haemotropic life style together with transmission by blood-sucking arthropods appears to provide a unique parasitic strategy for all Bartonella spp. However, each species seems to be highly adapted to one or a few mammalian hosts, causing a haemotropic infection characterized by the ability to parasitize erythrocytes intracellularly. Two species, Bartonella bacilliformis and Bartonella quintana, are adapted to humans as reservoir host causing oroya fever/verruga peruana and trench fever, respectively (Dehio \& Sander, 1999). In contrast, incidental infection of humans as non-reservoir hosts does not appear to lead to erythrocyte invasion but may cause various clinical manifestations (Dehio \& Sander, 1999). Transmission to a non-reservoir host can either occur directly via 
blood to blood contact or indirectly via haematophagous arthropods such as fleas or lice. For public health management, it is important to evaluate the presence of Bartonella species as a potential cause of zoonosis in those animals to which humans are prominently exposed. Cat-associated Bartonella henselae and Bartonella clarridgeiae (Gurfield et al., 1997; Heller et al., 1997; Kordick et al., 1997), Bartonella elizabethae naturally infecting rats (Daly et al., 1993; Ellis et al., 1999), Bartonella grahamii (Kerkhoff et al., 1999) and Bartonella vinsonii subsp. arupensis typically found in mice (Welch et al., 1999), as well as Bartonella vinsonii subsp. berkhoffii from a dog reservoir (Roux et al., 2000), have all been associated with human infection and therefore represent zoonotic pathogens.

In this study we have investigated the presence of Bartonella in wild roe deer (Capreolus capreolus). These animals represent the most widely spread game in Western Europe that is hunted in large numbers (in Germany more than 1000000 animals are shot per year). By typical hunting practice, hunters and forestry officials ( $>300000$ individuals in Germany) are exposed to direct contact with animal blood, especially during evisceration with bare hands. Accidental injury may bear the risk of direct blood to blood contact and result in infection with Bartonella spp. Moreover, a recent study detected Bartonella DNA in more than $70 \%$ of the ticks collected from roe deer (Schouls et al., 1999), suggesting that ticks may serve as an arthropod vector for transmission of bartonellae. Here we report the isolation of a new Bartonella species from the blood of wild roe deer. The prevalence of this species in roe deer of south-western Germany seems to be high and strains belonging to this new species appear to be highly diverse.

\section{METHODS}

Culture of Bartonella type and reference strains. Bartonella spp. were grown on Columbia agar base with $5 \%$ defibrinated sheep blood. Plates were incubated at $37^{\circ} \mathrm{C}$ in a moist atmosphere containing $5 \% \mathrm{CO}_{2}$ for $4-5 \mathrm{~d}$, except for Bartonella bacilliformis which was cultured at $30^{\circ} \mathrm{C}$ in a humidified atmosphere for up to $10 \mathrm{~d}$. The following type and reference strains were used for biochemical assays, PCR and DNA relatedness studies: Bartonella bacilliformis ATCC 35685 $5^{\mathrm{T}}$, Bartonella clarridgeiae strain 73 (Heller et al., 1997), Bartonella doshiae ATCC 700133 ${ }^{\mathrm{T}}$, Bartonella elizabethae ATCC $49927^{\mathrm{T}}$, Bartonella henselae ATCC $49882^{\mathrm{T}}$, Bartonella grahamii ATCC $700132^{\mathrm{T}}$, Bartonella koehlerae ATCC 700693 ${ }^{\mathrm{T}}$, Bartonella quintana CIP 103739 , Bartonella tribocorum CIP $105476^{\mathrm{T}}$, Bartonella vinsonii subsp. arupensis ATCC $700727^{\mathrm{T}}$, Bartonella vinsonii subsp. berkhoffii ATCC $51672^{\mathrm{T}}$ and Bartonella vinsonii subsp. vinsonii, ATCC VR-152 .

Isolation of bacterial strains. Bartonella isolates were cultured from the blood of wild roe deer. Blood was drawn within 45 min of death of the animal and frozen at $-80^{\circ} \mathrm{C}$. Thawed blood $(200 \mu \mathrm{l})$ was streaked onto blood agar plates made with a Columbia agar base supplemented with $5 \%$ defibrinated sheep blood. Incubation of the plates was performed at $37^{\circ} \mathrm{C}$ in a moist atmosphere containing $5 \%$
$\mathrm{CO}_{2}$. The count (c.f.u. $\mathrm{ml}^{-1}$ ) was determined for each blood agar plate.

Light microscopic examination. Colony phenotypes were observed using a binocular microscope at a magnification of $\times 5$. Gram-staining of the cultured micro-organisms was performed using standard methods (Chapin et al., 2000) and examined with an oil-immersion objective at a magnification of $\times 1000$.

Electron microscopy. Bacteria were prepared for electron microscopy as described by Fussenegger et al. (1996). Briefly, plate-grown bacteria were suspended in PBS, spread on a water surface and absorbed to Formvar-coated nickel grids. The grids were stained in $1 \%$ uranylacetate and air-dried. The samples were viewed under a Zeiss M109 electron microscope at $80 \mathrm{kV}$.

Biochemical analysis. Biochemical testing of the roe deer isolates as well as of other Bartonella species was performed essentially as described previously (Sander et al., 1997; Sander, 1998; Chapin et al., 2000). Bartonella species are biochemically inert in almost all conventional tests and detection of enzyme activities was performed with test kits which are primarily designed for the identification of anaerobes. However, Bartonella species are not included in their databases. The RapID ANA II system (Innovative Diagnostic Systems) and Rapid ID 32 A (BioMérieux) were used to test the activity of preformed bacterial enzymes in accordance with the manufacturer's instructions regarding preparation, incubation and biochemical interpretation. Leucyl-aryl-amidase activity was tested in the Api Strep system (BioMérieux).

Cellular fatty acid analysis. Fatty acid methyl esters were extracted from plate-grown bacteria and chromatographed on a Hewlett Packard series II 5890 gas chromatograph as described by Miller \& Berger (1985). The molecules were identified by using a computer-assisted comparison of their retention times with a standard mixture (Microbial Identification System).

Protein profiles (SDS-PAGE analysis). One-dimensional analytical SDS-PAGE was performed by the method of Laemmli (1970) with a $12 \%$ separating gel and a $4.5 \%$ stacking gel. Low-molecular-mass standards (Bio-Rad) were used to estimate the molecular mass of the separated proteins. The gel was stained with Coomassie blue R-250 (Serva).

Chromosomal DNA preparation. Bacterial DNA was extracted using Qiagen Genomic-tip according to the manufacturer's instructions.

Enterobacterial repetitive intergenic consensus (ERIC)-PCR. ERIC-PCR was performed as described by Sander et al. (1998a). The primers ERIC1R (5'-ATGTAAGCTCCTGGGGATTCAC-3') and ERIC2 (5'-AAGTAAGTGACTGGGGTGAGAGCG-3') used in this study have been described by Versalovic et al. (1991). The reaction mixture contained $8 \mathrm{ng}^{-1} \mathrm{l}^{-1}$ bovine serum albumin (Sigma), $200 \mu \mathrm{M}$ (each) of the four dNTPs, primers (117 nM each), 2 U Taq polymerase (Pharmacia Biotech) and $100 \mathrm{ng}$ genomic DNA in $50 \mu \mathrm{l}$ Tris borate/EDTA buffer. PCR amplification was performed with initial denaturation $\left(95^{\circ} \mathrm{C}, 7 \mathrm{~min}\right)$, followed by 30 cycles of denaturation $\left(94^{\circ} \mathrm{C}, 1 \mathrm{~min}\right)$, annealing $\left(40^{\circ} \mathrm{C}, 1 \mathrm{~min}\right)$ and extension $\left(65^{\circ} \mathrm{C}, 8 \mathrm{~min}\right)$ with a single final extension $\left(65^{\circ} \mathrm{C}, 16 \mathrm{~min}\right)$. The amplified products $(20 \mu \mathrm{l})$ were electrophoretically separated in a $1 \%$ agarose gel at $120 \mathrm{~V}$ for $2 \mathrm{~h}$ in $0.5 \times$ Tris borate/EDTA buffer, 
stained with ethidium bromide, visualized on an UV transilluminator and photographed with Polaroid 665 film.

Amplification of the 16S rRNA and citrate synthase (g/tA) genes. Amplification of the 16S rRNA and citrate synthase genes was performed as described by Birtles \& Raoult (1996) and Heller et al. (1997). Briefly, PCR amplification of an approximately $1500 \mathrm{bp}$ DNA fragment was performed with the 16S rRNA gene eubacterial universal oligonucleotide primers P8 and Pc1544 (Heller et al., 1997). For the gltA gene, the oligonucleotide primers used for the amplification were CS140f and BhCS.1137n (Birtles \& Raoult, 1996). Standard procedures to prevent sample DNA contamination were taken (Kwok \& Higuchi, 1989). Negative controls were included in each experiment to check for the absence of cross-contamination between samples and between previously amplified products and field samples.

Purification of the amplified product and DNA sequencing. The amplified DNA fragments were purified by Geneclean glass beads (Bio101; Dianova). Sequencing reactions were performed by the AmpliTaq BigDyeTerminator Cycle Sequencing Ready Reaction Kit (Perkin Elmer). Sequences were obtained with an ABI 377 DNA sequencer (Applied Biosystems). Sequencing of the complete 16S rRNA gene fragment was performed on coding and complementary strands, with four pairs of oligonucleotide primers as described previously (Heller et al., 1999). Partial sequencing of the glt $A$ gene was performed with two pairs of oligonucleotide primer: BhCS.1137n and BhCS.781p (Norman et al., 1995), and prCHD205 (5'-TATAAGCCATAGCAGCAAGAG-3') and CS140F (Birtles \& Raoult, 1996).

Sequence analysis. The sequences obtained were compared with similar sequences from other bacteria, including all Bartonella spp. contained in the EMBL/GenBank database. The sequences were aligned by using the CLUSTAL $\mathrm{W}$ program (Thompson et al., 1994; http://www.ebi.ac.uk/clustalw/) and multiple alignments were edited using Jalview (http://www.ebi.ac.uk/ michele/jalview/contents.html). Phylogenetic trees were generated by the neighbour-joining method (Saitou \& Nei, 1987) using CLUSTAL w and visualized by the software TREEVIEW (Page, 1996; http:// taxonomy.zoology.gla.ac.uk/rod/treeview.html).

DNA relatedness determination. DNA relatedness experiments by the hydroxyapatite method have been described by Brenner et al. (1982). DNA was labelled in vitro with $\left[{ }^{32} \mathrm{P}\right] \mathrm{dCTP}$ using a nick-translation kit (Gibco). The temperature used for optimal hybridization was $55^{\circ} \mathrm{C}$ and for stringent hybridization $70^{\circ} \mathrm{C}$, and divergence was calculated to the nearest $0.5 \%$. All reactions were done at least twice.

\section{RESULTS}

\section{Roe deer population and bacterial culture}

Blood samples from five wild roe deer (designated $\mathrm{R} 1^{\mathrm{T}}$, R2, R3, R4 and R6) were collected aseptically within 45 min of death. The roe deer had been shot between September and December 1999 either in the Schönbuch Nature Park or the woodland area of the Spitzberg, both territories being situated in the vicinity of the city of Tübingen in south-western Germany. Before killing, all animals appeared healthy and no particular abnormalities in inner organs (i.e. liver, spleen, heart and lymph nodes) were observed during

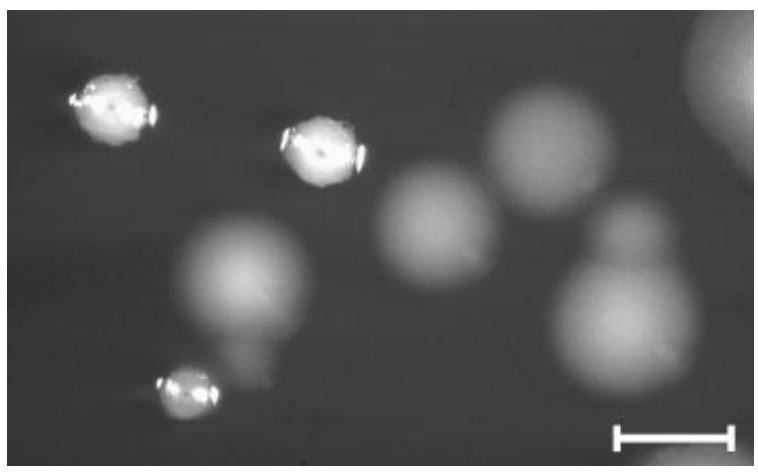

Fig. 1. Colony dimorphism of strain $R 1^{\top}$ at second-passage on blood agar after $8 \mathrm{~d}$ of growth. Bar, $2 \mathrm{~mm}$.

evisceration, especially in relation to Bartonella infection.

\section{Bacterial culture}

Plates streaked with blood from R2 remained sterile for more than 2 weeks, while on the plates streaked with the four remaining blood samples (of R $1^{\mathrm{T}}, \mathrm{R} 3, \mathrm{R} 4$ and R6), bacterial colonies appeared 4-6 d after inoculation and continued to grow for several days. The titre of colony-forming organisms in the various blood samples ranged from approximate 1000 to 10000 c.f.u. $(\mathrm{ml} \text { blood })^{-1}$. Primary colonies had a characteristic firm, adherent, deeply invaginated, cauliflower-like morphology. After the first passage, a shiny, smooth colony phenotype appeared in addition (Fig. 1), which, due to more rapid growth, outgrew the primary colony phenotype upon multiple passages and was therefore used for further analysis.

\section{Phenotypic identification}

Light microscopic examination of the Gram-stained micro-organisms showed small, pleomorphic Gramnegative rods. They were often very short and slightly curved. Electron microscopic examination showed small rods with multiple, unipolar flagella (Fig. 2).

\section{Biochemical analysis}

In biochemical testing, the four new isolates tested were negative for catalase, oxidase, indole and urea hydrolysis. All the new strains were positive for leucylaryl-amidase activity (LAP) in the Api Strep system. In the RapID ANA II system the reaction profiles of the new isolates were 000671 , which is identical to that of Bartonella henselae, Bartonella quintana and several other Bartonella spp. In detail, enzymic hydrolysis of D-disaccharide (BLTS), L-arabinoside (aARA), D-galactoside (ONPG), D-glucoside (aGLU), D-galactoside (BGLU), L-fucoside (aFUC), Dglucosaminide (NAG), p-nitrophenylphosphate (PO4) and pyrrolidonyl (PYR) were negative. A strong 


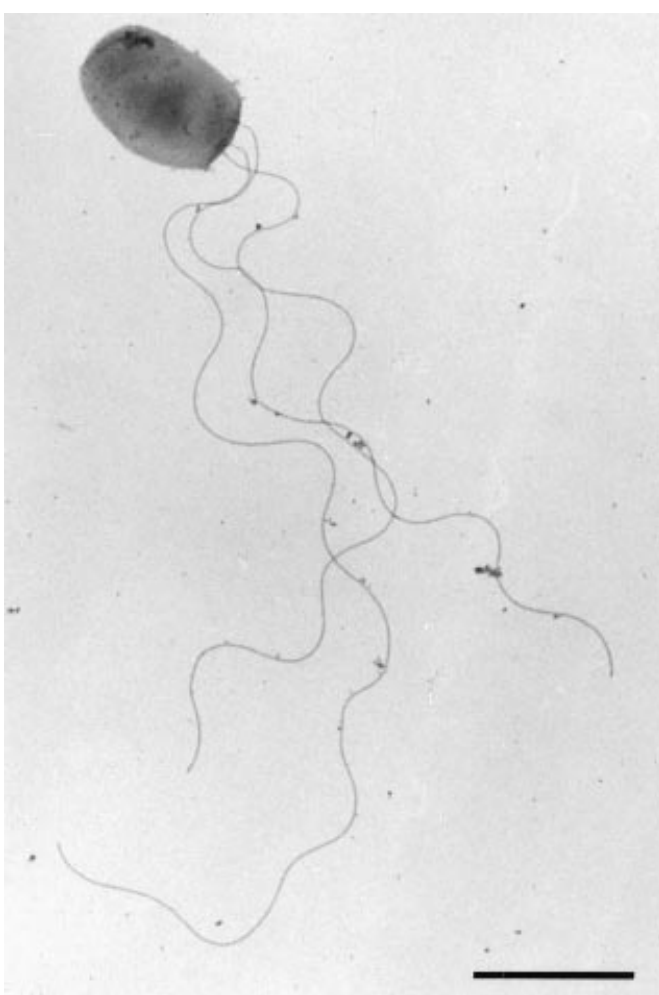

Fig. 2. Negative staining of strain $R 1^{\top}$. Bar, $1 \mu \mathrm{m}$.

positive reaction was seen in the enzymic hydrolysis of leucyl-glycine (LGY), glycine (GLY), arginine (ARG) and serine (SER). The hydrolysis of proline (PRO) and arginine (ARG) was less pronounced but clearly positive. Using this test system, Bartonella clarridgeiae and Bartonella doshiae are the only strains showing enzymic hydrolysis of D-glucosaminide (NAG).

The biotype code of the new isolates in the Rapid ID 32A system was 0000073705 for strains R $1^{\mathrm{T}}$, R3 and $\mathrm{R} 4$, which are therefore indistinguishable from that of Bartonella henselae, Bartonella quintana and several other Bartonella species. Amino acid arylamidase activity was obtained with the following amino acids: arginine (ArgA), proline (ProA), leucyl-glycine (LGA), phenylalanine (PheA), leucine (LeuA), tyrosine (TyrA), alanine (AlaA), glycine (GlyA), histidine (HisA) and serine (SerA). In contrast, isolate R6 was lacking LGA and is therefore biochemically different from the other strains (code 00000337 05).

\section{Cellular fatty acid analysis}

The major fatty acids of the four new Bartonella isolates are cis-11-octadecanoic acid $\left(\mathrm{C}_{18: 1} \omega 7 \mathrm{c}\right)$, which accounted for $42 \cdot 39-49 \cdot 85 \%$ of total acids, octadecanoic acid $\left(\mathrm{C}_{18: 0}\right), 34 \cdot 45-37 \cdot 04 \%$ of total acids, and hexadecanoic acid $\left(\mathrm{C}_{16: 0}\right), 11 \cdot 76-15.99 \%$ of total acids. Very small amounts of $\mathrm{C}_{12: 0} 3 \mathrm{OH}(0 \cdot 55-0 \cdot 69 \%)$ and $\mathrm{C}_{17: 0}(0 \cdot 00-0 \cdot 45 \%)$ were present but no cyclo-

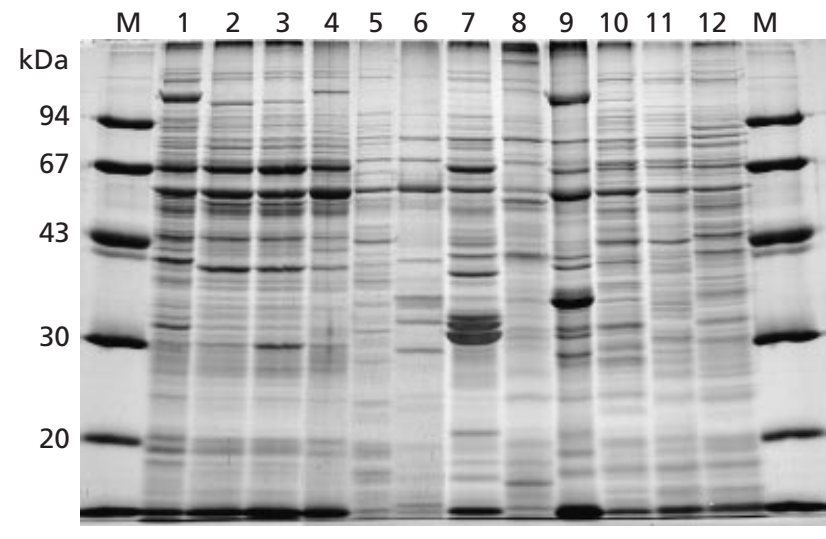

Fig. 3. SDS-PAGE analysis of total bacterial protein extracts of the four roe deer isolates as well as other Bartonella species. Extracts of total bacterial protein were separated by SDS-PAGE and stained with Coomassie brilliant blue. Lanes: M, molecular mass markers; 1, R1 $;$; 2, R3; 3, R4; 4, R6; 5, Bartonella henselae; 6, Bartonella quintana; 7, Bartonella bacilliformis; 8, Bartonella elizabethae; 9, Bartonella clarridgeiae; 10, Bartonella alsatica; 11, Bartonella tribocorum; 12, Bartonella grahamii.

propane acids were detected. These fatty acid patterns are similar to those observed for other Bartonella species (Sander, 1998).

\section{SDS-PAGE analysis}

Coomassie blue-stained SDS-polyacrylamide gels of total bacterial protein extracts of the four roe deer isolates showed three distinct protein profiles: $\mathrm{R} 3$ and $\mathrm{R} 4$ were similar, but $\mathrm{R} 1^{\mathrm{T}}$ and $\mathrm{R} 6$ were different (Fig. $3)$. Distinct protein profiles were found for all the different Bartonella species tested (Fig. 3).

\section{ERIC-PCR}

The analysis of the four roe deer isolates by ERICPCR confirmed the results obtained by SDS-PAGE: strains R3 and R4 showed an identical banding pattern which was different from those obtained from strains $\mathrm{R} 1^{\mathrm{T}}$ or R6. The fingerprint patterns of all other known Bartonella species are clearly different from those of the four roe deer isolates (Fig. 4).

\section{S rRNA and gltA gene sequence analysis}

A $1446 \mathrm{bp}$ region of the 16S rRNA gene sequence, corresponding to Escherichia coli positions 23-1521, was determined for the four roe deer isolates. Compared to strain R ${ }^{\mathrm{T}}$, strains R3, R4 and R6 had a single substitution of an adenosine by a cytosine residue at position 1021 (E. coli numbering system) (corresponding to $99.9 \%$ sequence identity). The sequences of the roe deer isolates were aligned with the 16S rRNA gene sequences of all other Bartonella species and with Brucella abortus as an outgroup. The GenBank accession numbers and strain designations for the 


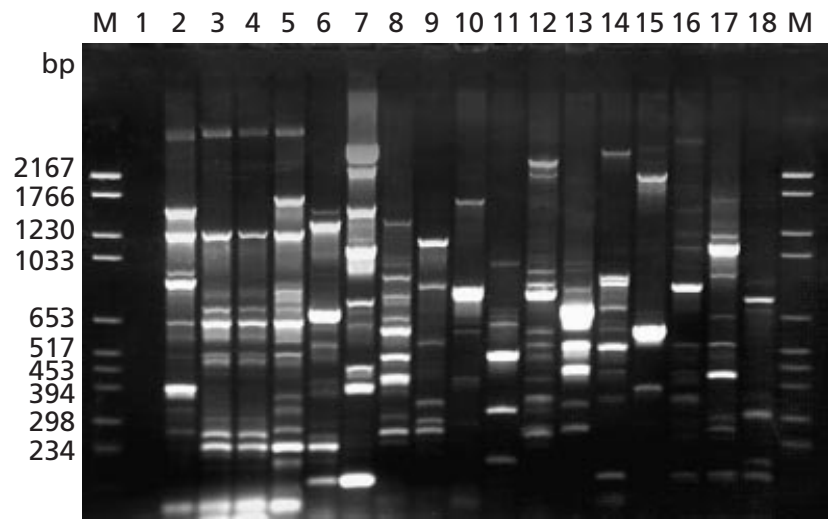

Fig. 4. DNA fingerprint analysis of the four new isolates and other Bartonella species by ERIC-PCR. Lanes: $\mathrm{M}$, molecular mass markers; 1 , negative control; $2, \mathrm{R}^{\top} ; 3, \mathrm{R} 3 ; 4, \mathrm{R} 4 ; 5, \mathrm{R} 6 ; 6$, Bartonella henselae; 7, Bartonella quintana; 8, Bartonella bacilliformis; 9, Bartonella elizabethae; 10, Bartonella clarridgeiae; 11, Bartonella alsatica; 12, Bartonella tribocorum; 13, Bartonella grahamii; 14, Bartonella doshiae; 15, Bartonella vinsonii spp. arupensis; 16, Bartonella vinsonii spp. berkhoffii; 17, Bartonella vinsonii spp. vinsonii; 18, Bartonella koehlerae.

sequences used in the alignment are given in Table 1. Sequences in the alignment extending the fully aligned core region were deleted, resulting in a 1379 base sequence consisting of region 28-1459 (E. coli numbering). The multiple alignment was used to generate a phylogenetic tree (Fig. 5a), which indicated that the roe deer sequences were most similar to Bartonella bacilliformis (corresponding to $98.0 \%$ sequence identity with $\mathrm{R} 1^{\mathrm{T}}$ ).
The glt $A$ gene sequence was determined for a region of 1013 bp (strain R1 $1^{\mathrm{T}}$ ), $1026 \mathrm{bp}$ (strain R3), $1025 \mathrm{bp}$ (strain R4) or $1034 \mathrm{bp}$ (strain R6). A phylogenetic tree was generated based on a sequence alignment for the roe deer isolates together with all available glt $A$ sequences from other Bartonella species which cover a similar size range, as well as Sinorhizobium meliloti which served as the outgroup (Fig. 5b). The GenBank accession numbers and strain designations for the sequences used in the alignment are given in Table 1. Sequences in the alignment extending the shortest sequence included (Bartonella grahamii) were deleted, resulting in a 903 base sequence consisting of region 557-1459 of the Sinorhizobium meliloti sequence. For the roe deer isolates this tree reflects a much higher sequence diversity in the glt $A$ gene than observed for the 16S rRNA gene (sequence identities: 98.0\% between $\mathrm{R} 1^{\mathrm{T}}$ and $\mathrm{R} 3 / \mathrm{R} 4 ; 96.8 \%$ between $\mathrm{R} 1^{\mathrm{T}}$ and $\mathrm{R} 6$; and $96.6 \%$ between R3/R4 and R6), while the four strains form a discrete cluster most closely related to Bartonella bacilliformis $(86.6 \%$ sequence similarity with $\mathrm{R} 1^{\mathrm{T}}$ ).

\section{DNA hybridization studies}

The results of DNA-relatedness studies are given in Table 2. The levels of DNA hybridization between the four roe deer isolates ranged from 76 to $100 \%$ under optimal hybridization conditions $\left(55^{\circ} \mathrm{C}\right)$ and from 56 to $100 \%$ under stringent $\left(70{ }^{\circ} \mathrm{C}\right)$ hybridization conditions with divergence levels of $0 \cdot 0-2 \cdot 5^{\circ} \mathrm{C}$. The percentage relatedness between the roe deer isolates and the type strains of other Bartonella spp. was less than $69 \%$ under optimal conditions and less than $43 \%$

Table 1. Strain designation and GenBank accession numbers for sequences in $16 \mathrm{~S}$ rRNA gene and $g / t A$ gene trees

\begin{tabular}{|c|c|c|c|}
\hline \multirow[t]{2}{*}{ Organism } & \multirow[t]{2}{*}{ Strain } & \multicolumn{2}{|c|}{ GenBank accession no. } \\
\hline & & 16S rRNA & glt $A$ \\
\hline Bartonella alsatica & CIP $105477^{\mathrm{T}}$ & AJ002139 & \\
\hline Bartonella bacilliformis & LA6.3 & Z70003 & Z70021 \\
\hline Bartonella clarridgeiae & ATCC $51734^{T}$ & X89208 & U84386 \\
\hline Bartonella doshiae & ATCC700133 & Z31351 & Z70017 \\
\hline Bartonella elizabethae & ATCC $49927^{\mathrm{T}}$ & L012560 & Z70009 \\
\hline Bartonella henselae & ATCC $49882^{\mathrm{T}}$ & M73229 & L38987 \\
\hline Bartonella grahamii & ATCC $700132^{\mathrm{T}}$ & Z31349 & Z70016 \\
\hline Bartonella koehlerae & ATCC $700693^{\mathrm{T}}$ & AF076237 & \\
\hline Bartonella quintana & ATCC VR-358 & M11927 & Z70014 \\
\hline Bartonella taylorii & NCTC $12861^{\mathrm{T}}$ & Z31350 & Z70013 \\
\hline Bartonella tribocorum & CIP $105476^{\mathrm{T}}$ & AJ003070 & AJ005494 \\
\hline Bartonella vinsonii subsp. vinsonii & ATCC VR-152T & L01259 & Z70015 \\
\hline Brucella abortus & $11-19$ & X13695 & \\
\hline \multirow[t]{5}{*}{ Sinorhizobium meliloti } & $104 \mathrm{~A} 14$ & & U75365 \\
\hline & $\mathrm{R} 1^{\mathrm{T}}$ & AJ278187 & AJ278183 \\
\hline & R3 & AJ 278188 & AJ278184 \\
\hline & $\mathrm{R} 4$ & AJ278189 & AJ278185 \\
\hline & R6 & AJ 278190 & AJ278186 \\
\hline
\end{tabular}


(a)

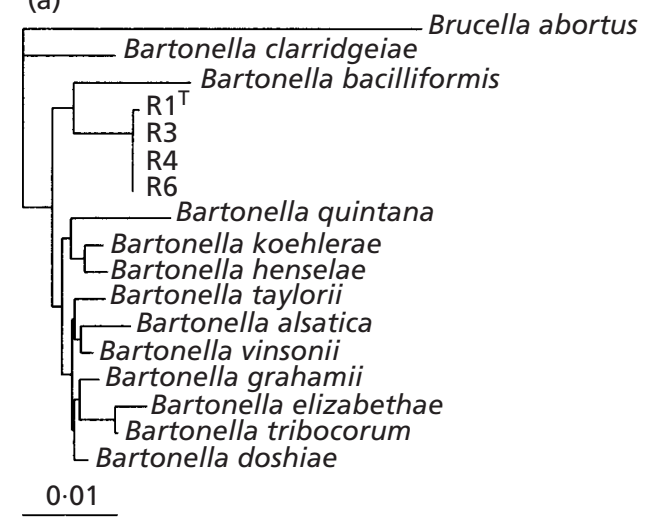

(b)

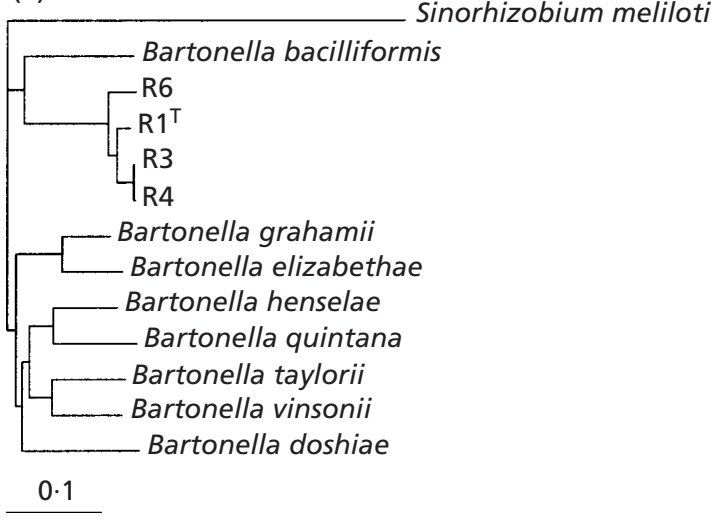

Fig. 5. Phylogenetic tree based on $16 \mathrm{~S}$ rRNA sequences (a) and gltA sequences (b) showing the position of strains $\mathrm{R} 1^{\top}, \mathrm{R} 3, \mathrm{R} 4$ and $\mathrm{R} 6$ in relation to the known Bartonella spp. The tree was rooted by using Brucella abortus (a) and Sinorhizobium meliloti (b) as the outgroup.

under stringent conditions, with divergence levels greater than $8.0 \%$. Since no strains of Bartonella taylorii, Bartonella talpae or Bartonella peromysci are available, it was not possible to include these species in the DNA hybridization studies. Among the Bartonella species tested, Bartonella henselae was found to be closely related to the roe deer strains under optimal hybridization conditions $\left(68 \%\right.$ at $\left.55^{\circ} \mathrm{C}\right)$, while Bartonella bacilliformis was found to be most closely related under stringent hybridization conditions ( $42 \%$ at $70{ }^{\circ} \mathrm{C}$ ).

\section{DISCUSSION}

Bartonella species have been identified as humanspecific pathogens (i.e. Bartonella bacilliformis and Bartonella quintana; Bass et al., 1997a) as well as important zoonotic agents (i.e. Bartonella henselae which naturally infects cats; Bass et al., 1997b). In the last 5 years, new Bartonella species have been isolated from a wide range of mammalian reservoirs, including rodents (Birtles et al., 1995; Heller et al., 1998), lagomorphs (Heller et al., 1999) and carnivores (Kordick et al., 1996), and a number of them have already been demonstrated to bear a significant zoonotic potential (Kordick et al., 1997; Ellis et al., 1999; Kerkhoff et al., 1999; Welch et al., 1999; Roux et al., 2000). In this study we have investigated the presence of bartonellae in roe deer. A previous study detected Bartonella DNA in more than $70 \%$ of the ticks collected from roe deer (Schouls et al., 1999), suggesting that this animal is frequently infected by bartonellae. Indeed, the recovery of four Bartonella strains from the blood of five roe deer from southwestern Germany indicates a high prevalence of bartonellae infection in this cervid. In North America, Bartonella isolates have been obtained in high frequency ( $90 \%$ prevalence of bacteraemia) from mule deer, another free-ranging wild cervid (Chang et al., 2000).

Primary cultures of the new isolates from roe deer were obtained on blood-enriched medium, as in the culture of other bartonellae. Primary colonies displayed a rough phenotype which changed to a smooth, fastgrowing phenotype during passages, a dimorphism which has been previously reported for Bartonella henselae (Regnery et al., 1992). In contrast to the often slow growth of primary cultures of other Bartonella species, primary colonies of Bartonella isolates from roe deer have been obtained within $4-6 \mathrm{~d}$ of incubation.

Biochemical profiles cannot be used routinely and reliably for the differentiation of Bartonella species because of the relatively inert nature of bartonellae. Among the four roe deer isolates, only strain R6 could be distinguished from Bartonella henselae or other Bartonella species by biochemical testing using preformed enzyme assays. Whole-cell fatty acid analysis provides a useful tool for the identification of Bartonella at the genus level but is a poor method for differentiating species. Consistently, cellular fatty acid of the four new isolates were found to be very similar to those of all other Bartonella species (high amounts of $\mathrm{C}_{18: 1} \omega 7 \mathrm{c}, \mathrm{C}_{18: 0}$ and $\mathrm{C}_{16: 0}$ ).

Repetitive element sequence-based PCR such as ERIC-PCR, has been successfully used for the identification of Bartonella strains on the species level as well to discriminate between isolates of the same species (Rodriguez-Barradas et al., 1995; Sander et al., 1998a). Using ERIC-PCR, we obtained from the four strains three different banding patterns, which were clearly different from all other Bartonella species. Three distinct protein profiles of the four new isolates were also found by SDS-PAGE. Consistently, DNA sequence analysis of the glt $A$ gene again revealed significant heterogeneity within the three distinct sequences. In contrast, $16 \mathrm{~S}$ rRNA sequences were less divergent, displaying a single base substitution in strain $\mathrm{R} 1^{\mathrm{T}}$ compared with the three others. These results provide evidence, not only for a clear distinction of the four strains from previously described species, but also for a significant heterogeneity among these strains, isolated from animals shot within an area of less than 
Table 2. DNA relatedness of Bartonella isolates from roe deer to other Bartonella species

\begin{tabular}{|c|c|c|c|c|c|c|c|c|c|}
\hline \multirow[t]{2}{*}{ Strain } & \multicolumn{3}{|c|}{$\mathbf{R} \mathbf{1}^{\mathrm{T}}$} & \multicolumn{3}{|c|}{ R4 } & \multicolumn{3}{|c|}{ R6 } \\
\hline & $55^{\circ} \mathrm{C}^{*}$ & $D \dagger$ & $70^{\circ} \mathrm{C} \ddagger$ & $55^{\circ} \mathrm{C}^{*}$ & $D \dagger$ & $70{ }^{\circ} \mathrm{C} \ddagger$ & $55^{\circ} \mathrm{C}^{*}$ & $D \dagger$ & $70^{\circ} \mathrm{C} \ddagger$ \\
\hline $\mathrm{R} 1^{\mathrm{T}}$ & 100 & $0 \cdot 0$ & 100 & 78 & $2 \cdot 5$ & 75 & 84 & $2 \cdot 5$ & 76 \\
\hline R3 & 77 & $2 \cdot 5$ & 61 & 99 & $0 \cdot 5$ & 96 & 95 & $1 \cdot 5$ & 84 \\
\hline $\mathrm{R} 4$ & 76 & $2 \cdot 5$ & 56 & 100 & $0 \cdot 0$ & 100 & 97 & $1 \cdot 0$ & 85 \\
\hline R6 & 89 & $2 \cdot 0$ & 82 & 99 & $0 \cdot 5$ & 97 & 100 & $0 \cdot 0$ & 100 \\
\hline Bartonella henselae & 68 & $8 \cdot 5$ & 34 & ND & $9 \cdot 5$ & 31 & ND & $9 \cdot 0$ & 33 \\
\hline Bartonella quintana & 66 & $10 \cdot 0$ & 40 & ND & $10 \cdot 0$ & 16 & ND & $10 \cdot 0$ & 26 \\
\hline Bartonella clarridgeiae & 61 & $10 \cdot 0$ & 35 & ND & $10 \cdot 0$ & 19 & ND & $8 \cdot 5$ & 25 \\
\hline Bartonella doshiae & 54 & $11 \cdot 0$ & 27 & ND & $10 \cdot 0$ & 18 & ND & $10 \cdot 5$ & 25 \\
\hline Bartonella vinsonii & 62 & $9 \cdot 0$ & 35 & ND & ND & ND & ND & ND & ND \\
\hline Bartonella grahamii & 58 & $9 \cdot 5$ & 28 & ND & ND & ND & ND & ND & ND \\
\hline Bartonella koehlerae & 59 & $10 \cdot 0$ & 35 & ND & ND & ND & ND & ND & ND \\
\hline Bartonella elizabethae & 56 & $10 \cdot 5$ & 27 & ND & ND & ND & ND & ND & ND \\
\hline Bartonella alsatica & 59 & $10 \cdot 5$ & 35 & ND & ND & ND & ND & ND & ND \\
\hline Bartonella tribocorum & 63 & $10 \cdot 0$ & 40 & ND & ND & ND & ND & ND & ND \\
\hline Bartonella bacilliformis & 62 & $8 \cdot 5$ & 42 & ND & ND & ND & ND & ND & ND \\
\hline
\end{tabular}

ND, Not determined.

* Relative binding ratio [(percentage heterologous DNA bound to hydroxyapatite/percentage homologous DNA bound by hydroxyapatite $) \times 100]$ at $55^{\circ} \mathrm{C}$.

$\dagger$ Divergence $(D)$ is the decrease in thermal stability (in degrees Celsius) of heterologous DNA duplexes compared with those of homologous DNA duplexes.

\$ Relative binding ratio [(percentage heterologous DNA bound to hydroxapatite/percentage homologous DNA bound by hydroxyapatite $) \times 100]$ at $70^{\circ} \mathrm{C}$.

$100 \mathrm{~km}^{2}$. Although differences between strains belonging to one species have previously been noted for other Bartonella species (Sander et al., 1998b), the heterogeneity observed in the roe deer isolates appears to be very prominent. However, the limited sample size of this study did not allow epidemiological observations. Further studies need to be conducted to determine the heterogeneity of Bartonella isolates among roe deer populations.

DNA-DNA hybridization remains the method of choice for defining a species. It has been recommended that a species be considered to consist of strains whose DNAs are $70 \%$ or more related under optimal DNA reassociation conditions and $55 \%$ or more related under stringent DNA reassociation conditions, with $5 \%$ or less divergence within related sequences (Brenner et al., 1982; Wayne et al., 1987). According to these conditions, all four isolates belong to a single new species, although the strains are so divergent that we could have described two different subspecies (i.e. for $\mathrm{R} 1^{\mathrm{T}}$ and for R3, R4 and R6) as has been done previously in the genus Bartonella (Kordick et al., 1996; Welch et al., 1999). This novel species is proposed and described below. Based on stringent DNA hybridization and phylogenetic trees obtained for the 16S rRNA and the glt $A$ gene sequences, the new Bartonella species is most closely related to Bartonella bacilliformis. Moreover, Bartonella bacilliformis together with Bartonella clarridgeiae are the only described Bartonella species which carry flagella as described here for all the roe deer isolates. Regarding the relatedness of the new Bartonella species to Bartonella bacilliformis as well as its considerable heterogeneity we speculate that this pathogen not only has the potential to cause zoonosis (i.e. in hunters and forestry personnel who are exposed to the blood of roe deer or who are infested by ticks), but also that variants may adapt to humans, eventually developing into a human-specific pathogen such as Bartonella bacilliformis.

\section{Description of Bartonella schoenbuchii sp. nov.}

Bartonella schoenbuchii (schoen.buch'i.i. N.L. gen. n. schoenbuchii from Schönbuch, a nature park near Tübingen in south-west Germany where most of the roe deer analysed in this study were shot).

Growth obtained on Columbia agar base supplemented with $5 \%$ defibrinated sheep blood in a moist atmosphere containing $5 \% \mathrm{CO}_{2}$. Colonies appear in primary culture within 4-6 d as firm adherent, deeply invaginated, cauliflower-like colonies which upon passaging may switch to a more rapidly growing, shiny and smooth colony phenotype. The Gramnegative, monopolar politrichous flagellated rods are approximately $1-2 \times 0.5 \mu \mathrm{m}$, aerobic and negative for oxidase, indole, catalase and urea hydrolysis. The code for preformed enzymes obtained in the RapID ANA II 
system is 000 671. The biotype code using Rapid ID 32A was 0000073705 or 0000033705 , depending on the strain analysed. The major fatty acids are cis-11octadecanoic acid $\left(\mathrm{C}_{18: 1} \omega 7 c\right)$, octadecanoic acid $\left(\mathrm{C}_{18: 0}\right)$ and hexadecanoic acid $\left(\mathrm{C}_{16: 0}\right)$, similar as observed for other Bartonella species. The four strains thus far isolated from the blood of healthy roe deer display phenotypic and genotypic differences but belong to a single new species. This new species is distinguished from previously known Bartonella species by the total protein profiles in SDS-PAGE, the banding patterns in the ERIC-PCR, the glt $A$ and 16S rRNA gene sequences, and by whole-DNA hybridization analysis. Type strain is $\mathrm{R} 1^{\mathrm{T}}$, isolated from the blood of a 4-month-old female wild roe deer. Deposited in the National Collection of Type Cultures as NCTC $13165^{\mathrm{T}}$ and the Deutsche Sammlung von Mikroorganismen und Zellkulturen as DSM $13525^{\mathrm{T}}$.

\section{ACKNOWLEDGEMENTS}

We thank Karl Ebert (Staatliches Forstamt TübingenBebenhausen) for the permission to shoot roe deer and collect their blood in the Schönbuch Nature Park and Karin Oberle, Hildegard Schulz and Bozena Pichler-Brand for their excellent technical assistance. Anja Seubert and Christopher Snyder are acknowledged for critical reading of the manuscript. This work was supported by grants from the German Research Foundation (DFG De 539/3-1) and the Swiss National Science Foundation (SNF 3100061777.00/1).

\section{REFERENCES}

Bass, J. W., Vincent, J. M. \& Person, D. A. (1997a). The expanding spectrum of Bartonella infections: I. Bartonellosis and trench fever. Pediatr Infect Dis $J$ 16, 2-10.

Bass, J. W., Vincent, J. M. \& Person, D. A. (1997b). The expanding spectrum of Bartonella infections: II. Cat-scratch disease. Pediatr Infect Dis J 16, 163-179.

Birtles, R. J. \& Raoult, D. (1996). Comparison of partial citrate synthase gene $(\mathrm{glt} A)$ sequences for phylogenetic analysis of Bartonella species. Int J Syst Bacteriol 46, 891-897.

Birtles, R. J., Harrison, T. G., Saunders, N. A. \& Molyneux, D. H. (1995). Proposals to unify the genera Grahamella and Bartonella, with descriptions of Bartonella talpae comb. nov., Bartonella peromysci comb. nov., and three new species, Bartonella grahamii sp. nov., Bartonella taylorii sp. nov., and Bartonella doshiae sp. nov. Int J Syst Bacteriol 45, 1-8.

Brenner, D. J., McWhorter, A. C., Knutson, J. K. \& Steigerwalt, A. G. (1982). Escherichia vulneris: a new species of Enterobacteriaceae associated with human wounds. J Clin Microbiol 15, 1133-1140.

Brenner, D. J., O'Connor, S. P., Winkler, H. H. \& Steigerwalt, A. G. (1993). Proposals to unify the genera Bartonella and Rochalimaea, with descriptions of Bartonella quintana comb. nov., Bartonella vinsonii comb. nov., Bartonella henselae comb. nov., and Bartonella elizabethae comb. nov., and to remove the family Bartonella ceae from the order Rickettsiales. Int J Syst Bacteriol 43, 777-786.

Chang, C., Chomel, B. B., Kasten, R. W. \& 18 other authors. (2000). Bartonella spp. isolated from wild and domestic ruminants in North America. Emerg Infect Dis 6, 306-311.
Chapin, K. C. \& Murray, P. R. (2000). Strains. In Manual of Clinical Microbiology, 7th edn, pp. 1674-1675. Edited by P. R. Murray, E. J. Baron, M. A. Pfaller, F. C. Tenover \& R. H. Yolken. Washington, DC: ASM Press.

Daly, J. S., Worthington, M. G., Brenner, D. J. \& 7 other authors, (1993). Rochalimaea elizabethae sp. nov. isolated from a patient with endocarditis. J Clin Microbiol 31, 872-881.

Dehio, C. \& Sander, A. (1999). Bartonella as emerging pathogens. Trends Microbiol 7, 226-228.

Ellis, B. A., Regnery, R. L., Beati, L. \& 7 other authors, (1999). Rats of the genus Rattus are reservoir hosts for pathogenic Bartonella species: an Old World origin for a New World disease? I Infect Dis 180, 220-224.

Fussenegger, M., Kahrs, A. F., Facius, D. \& Meyer, T. F. (1996). Tetrapac $(t p c)$, a novel genotype of Neisseria gonorrhoeae affecting epithelial cell invasion, natural transformation competence and cell separation. Mol Microbiol 19, 1357-1372.

Gurfield, A. N., Boulouis, H. J., Chomel, B. B., Heller, R., Kasten, R. W., Yamamoto, K. \& Piemont, Y. (1997). Coinfection with Bartonella clarridgeiae and Bartonella henselae and with different Bartonella henselae strains in domestic cats. J Clin Microbiol 35, 2120-2123.

Heller, R., Artois, M., Xemar, V., De Briel, D., Gehin, H., Jaulhac, B., Monteil, H. \& Piemont, Y. (1997). Prevalence of Bartonella henselae and Bartonella clarridgeiae in stray cats. J Clin Microbiol 35, 1327-1331.

Heller, R., Riegel, P., Hansmann, Y. \& 7 other authors, (1998). Bartonella tribocorum sp. nov., a new Bartonella species isolated from the blood of wild rats. Int J Syst Bacteriol 48, 1333-1339.

Heller, R., Kubina, M., Mariet, P. \& 9 other authors, (1999). Bartonella alsatica sp. nov., a new Bartonella species isolated from the blood of wild rabbits. Int J Syst Bacteriol 49, 283-288.

Kerkhoff, F. T., Bergmans, A. M., van Der Zee, A. \& Rothova, A. (1999). Demonstration of Bartonella grahamii DNA in ocular fluids of a patient with neuroretinitis. J Clin Microbiol 37, 4034-4038.

Kordick, D. L., Swaminathan, B. \& Greene, C. E. \& 11 other authors. (1996). Bartonella vinsonii subsp. berkhoffii subsp. nov., isolated from dogs; Bartonella vinsonii subsp. vinsonii; and emended description of Bartonella vinsonii. Int J Syst Bacteriol 46, 704-709.

Kordick, D. L., Hilyard, E. J., Hadfield, T. L., Wilson, K. H., Steigerwalt, A. G., Brenner, D. J. \& Breitschwerdt, E. B. (1997). Bartonella clarridgeiae, a newly recognized zoonotic pathogen causing inoculation papules, fever, and lymphadenopathy (cat scratch disease). J Clin Microbiol 35, 1813-1818.

Kwok, S. \& Higuchi, R. (1989). Avoiding false positives with PCR. Nature 339, 237-238.

Laemmli, U. K. (1970). Cleavage of structural proteins during the assembly of the head of bacteriophage T4. Nature 227, 680-685.

Miller, L. \& Berger, T. (1985). Bacterial Identification by Gas Chromatography of Whole Cell Fatty Acids. Avondale, PA: Hewlett-Packhard.

Norman, A. F., Regnery, R., Jameson, P., Greene, C. \& Krause, D. C. (1995). Differentiation of Bartonella-like isolates at the species level by PCR-restriction fragment length polymorphism in the citrate synthase gene. J Clin Microbiol 33, 1797-1803.

Page, R. D. (1996). TreeView: an application to display phylogenetic trees on personal computers. Comput Appl Biosci 12, 357-358.

Regnery, R. L., Anderson, B. E., Clarridge, J. E. D., RodriguezBarradas, M. C., Jones, D. C. \& Carr, J. H. (1992). Characterization 
of a novel Rochalimaea species, $R$. henselae sp. nov., isolated from blood of a febrile, human immunodeficiency virus-positive patient. J Clin Microbiol 30, 265-274.

Rodriguez-Barradas, M. C., Hamill, R. J., Houston, E. D., Georghiou, P. R., Clarridge, J. E., Regnery, R. L. \& Koehler, J. E. (1995). Genomic fingerprinting of Bartonella species by repetitive element PCR for distinguishing species and isolates. $J$ Clin Microbiol 33, 1089-1093.

Roux, V., Eykyn, S. J., Wyllie, S. \& Raoult, D. (2000). Bartonella vinsonii subsp. berkhoffii as an agent of afebrile blood culturenegative endocarditis in a human. $J$ Clin Microbiol 38, $1698-1700$

Saitou, N. \& Nei, M. (1987). The neighbor-joining method: a new method for reconstructing phylogenetic trees. Mol Biol Evol 4, 406-425.

Sander, A. (1998). Microbiological diagnosis of Bartonella species and Afipia felis. In Bartonella and Afipia Species Emphasizing Bartonella henselae. Contributions to Microbiology, vol. 1, pp. 98-112. Edited by A. Schmidt. Basel, Switzerland: Karger.

Sander, A., Buhler, C., Pelz, K., von Cramm, E. \& Bredt, W. (1997). Detection and identification of two Bartonella henselae variants in domestic cats in Germany. J Clin Microbiol 35, 584-587.

Sander, A., Ruess, M., Bereswill, S., Schuppler, M. \& Steinbrueckner, B. (1998a). Comparison of different DNA fingerprinting techniques for molecular typing of Bartonella henselae isolates. J Clin Microbiol 36, 2973-2981.
Sander, A., Ruess, M., Deichmann, K., Bohm, N. \& Bredt, W. (1998b). Two different genotypes of Bartonella henselae in children with cat-scratch disease and their pet cats. Scand $J$ Infect Dis 30, 387-391.

Schouls, L. M., Van De Pol, I., Rijpkema, S. G. \& Schot, C. S. (1999). Detection and identification of Ehrlichia, Borrelia burgdorferi sensu lato, and Bartonella species in Dutch Ixodes ricinus ticks. J Clin Microbiol 37, 2215-2222.

Thompson, J. D., Higgins, D. G. \& Gibson, T. J. (1994). CLUSTAL $\mathrm{W}$ : improving the sensitivity of progressive multiple sequence alignment through sequence weighting, position-specific gap penalties and weight matrix choice. Nucleic Acids Res 22, 4673-4680.

Versalovic, J., Koeuth, T. \& Lupski, J. R. (1991). Distribution of repetitive DNA sequences in eubacteria and application to fingerprinting of bacterial genomes. Nucleic Acids Res 19, 6823-6831.

Wayne, L. G., Brenner, D. J., Colwell, R. R. \& 9 other authors, (1987). International Committee on Systematic Bacteriology. Report of the ad hoc committee on reconciliation of approaches to bacterial systematics. Int J Syst Bacteriol 37, 463-464.

Welch, D. F., Carroll, K. C., Hofmeister, E. K., Persing, D. H., Robison, D. A., Steigerwalt, A. G. \& Brenner, D. J. (1999). Isolation of a new subspecies, Bartonella vinsonii subsp. arupensis, from a cattle rancher: identity with isolates found in conjunction with Borrelia burgdorferi and Babesia microti among naturally infected mice. J Clin Microbiol 37, 2598-2601. 